FESIEE

Fundación Emilio Soldevilla de la Investigación y Desarnosto de la Economia de la Empresa

\section{Management Letters / Cuadernos de Gestión}

journal homepage: http://www.ehu.eus/cuadernosdegestion/revista/es/

ISSN: 1131-6837 / e-ISSN: 1988-2157

\title{
Firms' internationalization through clusters: A keywords bibliometric analysis of 152 top publications in the period 2009-2018
}

\section{Internacionalización de empresas a través de clústeres: análisis bibliométrico de palabras clave de 152 publicaciones destacadas en el período 2009-2018}

\author{
Mohammad-Reza Mazandaraniª, Marcelo Royo-Vela* \\ a Department of Marketing and Market Research. Faculty of Economics. Universidad de Valencia, Avda de los Naranjos s $\backslash$, 46022 Valencia, Spain. - mazandar@ \\ alumni.uv.es - https://orcid.org/0000-0003-0682-6797
}

* Corresponding author: University Full Professor in the Department of Marketing and Market Research. Faculty of Economics. Universidad de Valencia, Avda de los Naranjos $\backslash \backslash n$, 46022 Valencia, Spain. - marcelo.royo@uv.es - https://orcid.org/0000-0002-9310-5201 - WoS Research ID: R-9875-2019; Corvinus Institute for Advanced Studies, Czuczor utca 10. second floor, 1093 Budapest, Hungary; marcelo.royovela@uni-corvinus.hu

\section{A R T I C L E I N F O}

Received 28 April 2021, Accepted 17 November 2021

Available online 10 February 2022

DOI: $10.5295 / \mathrm{cdg} .211483 \mathrm{mr}$

JEL: F06, R01

\begin{abstract}
A B S T R A C T
While countless studies on the role of clusters in regional economic developments and business performance have been done, some disadvantages and limitations also have been identified. Limitations such as small local markets, limited resources, isolation, and over-independence which lead companies to a lock-in state regarding knowledge and innovation can be solved by means of internationalization or foreign market expansion. Therefore, the internationalization of clusters still needs more attention. Furthermore, by conducting a bibliometric study based on the keywords from previous research, this investigation intends to identify the principal and most influential items, their relationship, and evolution, related to this topic. This work listed the top 30 journals based on SCImago Rank (SJR) in the category of Marketing, Management, and Internationalization, to select authoritative papers on the topic of internationalization of clusters. Based on the title, time of publication (2009 to 2018), and content, 152 articles were selected. Using SciMAT software, all 584 keywords used in these articles were first categorized and then examined in terms of the networks between them, their h-index, centrality, density, and their evolution over the course of ten years (divided into two five-year periods). The results show that in the first five years, keywords such as, Network, Location-distance, and Global, have been at the core of this research topic. While in the second five year period, these keywords have yielded their position to new subjects such as Social capital, Cluster-type, and Development. Moreover, this research correspondingly confirms that the keyword bibliometric analysis produces similar results to a quantitative content analysis. These results therefore open the door to updated research questions for further and better development of the topic.
\end{abstract}

Keywords: Clustering, bibliometric mapping, internationalization, keyword analysis, SciMAT, SJR.

\section{R E S U M E N}

Si bien el impacto de los clústeres en el desarrollo económico de las regiones se ha confirmado en innumerables estudios, también se han identificado algunas desventajas y limitaciones. Limitaciones como pequeños mercados locales, recursos limitados, aislamiento y sobre independencia que llevan a las empresas a un estado de encierro en cuanto al conocimiento y la innovación pueden resolverse mediante la internacionalización o la expansión del mercado exterior. Por tanto, la internacionalización de los clústeres todavía necesita más atención. Mediante la realización de un estudio bibliométrico sobre las palabras clave de investigaciones previas, esta investigación pretende identificar los elementos principales e influyentes, su relación y evolución, respecto a este tema. Este trabajo toma como referente, las 30 principales revistas indexadas en SCImago Rank (SJR) en la categoría de Marketing, Gestión e Internacionalización. Analizando el título la fecha de publicación (2009 a 2018) y el contenido se seleccionaron 152 artículos sobre la internacionalización del cluster. Los resultados muestran que, en los primeros cinco años, palabras clave como "Network, Location-distance, y Global", han sido centrales en la investigación de esta cuestión. Mientras que, en el segundo quinquenio, estos temas centrales de investigación han sido relevados por otros como el "Social capital, Cluster-type," y "Development". Además, esta investigación confirma que el análisis bibliométrico de palabras clave permite obtener resultados similares al análisis de contenido cuantitativo. Estos resultados identifican cuestiones a investigar más actualizadas para poder alcanzar un mayor y mejor desarrollo en esta línea de investigación.

Palabras clave: Clustering, mapeo bibliométrico, internacionalización, análisis de palabras clave, SciMAT, SJR. 


\section{INTRODUCTION}

Based on the influential Marshall-Arrow-Romer (1980) approach in the early 20th century and followed by the theory of cluster by Porter (1998), many geographic economists have investigated the advantages of firms' agglomeration for interactive learning, innovation, and regional development (Geldes et al., 2015). Porter (2000, p. 16) defines clusters as "geographic concentrations of interconnected companies, specialized suppliers, service providers, firms in related industries, and associated institutions (e.g., universities, standards agencies, trade associations), in a particular field that compete but also cooperate". According to this definition, proximity and location received special attention in the geographic economy. For instance, Brink (2018) confirms that geographical concentration leads to an increase in existing capacities of the expert workforce. In addition, the presence of these experts, and their official and unofficial communications, can improve the scientific knowledge base of regional entities and organizational effectiveness (Janney \& Gove, 2011). Moreover, suppliers find the market suitable enough to present their products, and, various industries and companies face fewer problems in providing the necessary raw materials; hence, they can benefit from competitive advantages as a result (Liao, 2010). As industries and companies grow, their knowledge and information flows into clusters; thus, smaller start-ups can also enjoy this overflow of knowledge and information (Jia et al., 2017). In short, successful clusters will acquire credibility and popularity, and attract an expert workforce, as well as; suppliers, domestic and foreign investors, and customers. All these factors improve the regional economy, innovation, and competition (Porter, 2000).

However, from the very beginning, Porter (2000) had commented that foreign market expansion as a solution to the clusters limitations (i.e. lack of raw materials, labour, and limited local markets) (Porter, 2000; Watson IV et al., 2018), and technology advancements has lead clusters to seek supplements for their lost geographic proximity advantage (Boschma, 2005). In other words, isolation and over-dependence in a cluster may hinder interactive learning and innovation, so invested parties must keep their flexibility, and relationship with outside of the cluster (Boschma, 2005) to avoid a state of inertia and lock-in. For this reason, the internationalization of clusters has been considered by academics and governments ${ }^{1}$ most recently (ECCP, 2021), and it has been concluded that it still needs more attention.

Undoubtedly, reviewing literature is important to the dissemination of knowledge on a specific issue (Martínez-Fernández et al., 2012; Muñoz-Leiva et al., 2012). In general, content analysis is a qualitative method that is recognized as the most valid analytical system for reviewers (Weismayer \& Pezenka, 2017). The results of these qualitative methods are impressive, but their implementation also takes a lot of time and work. Most recently, researchers, with the help of technology, have taken big steps towards "intelligent text mining approaches", that require far less effort and time (Weismayer \& Pezenka, 2017, p. 1758).

Internationalization is one of the most important topics for the European Cluster Collaboration Platform's (ECCP's) research, funds, and projects during recent years.
Consequently, bibliometric analysis, among all techniques, has received more attention as a qualitative approach, which creates realistic viewpoints about the content and structure of a research topic (Ding et al., 2001; Weismayer \& Pezenka, 2017). Furthermore, thanks to advances in technology, the literature bibliometric review is not as complicated as before. Nowadays, computational text analytic programs have facilitated this qualitative analytical method (Cobo et al., 2012).

There are several techniques that are applicable to these analytical programs in a bibliometric review. Muñoz-Leiva et al., (2012) mentioned keyword analysis as the most popular technique for such quantitative investigations. This research used all the main keywords proposed by authors in each article to identify relevant items and their relationship to the core topic of cluster internationalization.

Therefore, the aim of this paper is to review the literature on cluster internationalization, in order to obtain a comprehensive framework on this topic, and identify the most used sub-factors, their relationship, and evolution, during a specific time period. Based on the intended objectives, the following questions were raised:

1. What keywords are most often used in the internationalization literature of clusters?

2. In terms of density and centrality, how have these keywords been used together?

3. How has the evolution of using these keywords been over the selected 10-year period?

To answer the research questions, we broke down this keyword bibliometric analysis into several steps. First, this research employed SCImago Journal Rank (SJR) to identify the top 30 scholarly journals in marketing and management. The ranking of the selected journals were confirmed by reviewing their JCR (Journal Citation Report) impact factor. Then, we used Google's scholarly advanced search to select articles with related keywords to cluster internationalization between $1 / 1 / 2009$ and 1/1/2019. Next, we checked the content of articles using the NVIVO program and collected 584 keywords proposed by authors in 152 papers. Finally, we set two 5-year periods to analyse the collected data by SciMAT software (Cobo et al., 2012).

As a result, the research has the following sections. In Section 2, more comprehensive information is provided on methods employed to select relevant data and analysis tools and methods; Section 3 presents the results and discussion; Section 4 gives conclusions; and finally, limitations and implications for future research are presented in Section 5.

\section{RESEARCH METHODOLOGY IN BIBLIOMETRIC ANALYSIS}

Depending on the research objectives, researchers use a variety of approaches to review articles (Weismayer \& Pezenka, 2017). According to Üsdiken \& Pasadeos (1995), the review method is implacable in six approaches, such as, quantity of publications, co-citation analysis, comprehensive reviews, methodological investigations, analysing specific journals, and meta-analysis. Specifically, bibliometric is used as a qualitative method to "describe research patterns and to identify relations between those docu- 
ments" (Weismayer \& Pezenka, 2017, p. 1759). As a qualitative approach, keyword analysis is one of the most recommended methods for bibliometric analysis (Muñoz-Leiva et al., 2012).

Considering the paradox on the topic of clustering and internationalization, the internationalization of clusters is a challenging issue. One of the best ways to achieve a complete perception is to conduct a detailed review of existing documents through bibliometric mapping analysis (Cobo et al., 2011). This method analyses the repetition of keywords used, searches the literature, integrates the analysis (Fahimnia et al., 2015), and illustrates the relationships between the selected documents and/or their contents, in order to determine the type and extent of these relationships, as well as their evolution process (Cobo et al., 2012). Nevertheless, thanks to technological advances, with new software, this work is not as difficult as before.

Accordingly, this research used one of the most comprehensive science mapping software tools available, SciMAT. Cobo et al. (2012) analysed the strengths and weaknesses of nine bibliometric mapping software tools, in order to develop this multifunctional software that can perform a mapping analysis within a longitudinal framework. This software tool also carries out all mapping steps including measurement, algorithm design, and visualization of the results, in the general science context; thus, researchers can perform their studies by using these findings. In addition, to organize the input information and use it to perform the necessary measurements and analyses, this software tool incorporates all the features and instruments embedded in similar software and provides a clear understanding of the results (Cobo et al., 2012, p.1609).

Following the software instructions, we conducted an eightstep methodology to collect and analyse the keywords from selected articles (Figure 1). This comprehensive method has been established to identify the top studies, determine the most important items in this topic, and facilitate future investigation.

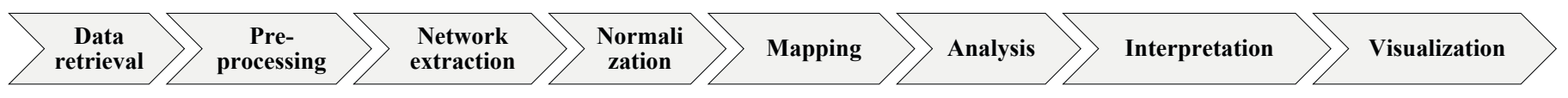

Figure 1

"Workflow of science mapping"

Source: Cobo et al. (2012, p. 1610).

\subsection{Data collection and software used (Step 1)}

In this research, the data have been collected in several steps. In order to identify top journals in the area of marketing and international business management we used SCImago Journal Rank (SJR). This journal citation ranking is one of the best sources for a bibliometric database (Cobo et al., 2011), which has been receiving more attention in recent (Coimbra et al., 2019; Niñerola et al., 2019). First of all, SJR is a free database (Mojgani et al., 2020), which facilitates resource accessibility. Furthermore, as Juliani \& Oliveira (2016, p. 1036) mentioned, "SJR takes into account the prestige of the citing scientific journal and its closeness to the cited journal". In other words, it measures citations based on their origins (Mojgani et al., 2020). Thus, 30 top journals were selected, and to reconfirm the transparency of collected data, authors also checked the Citation Reports ${ }^{\mathrm{TM}}$ (JCR) of each journal. Related to our research topic, Internationalization and Cluster are two main keywords used for selecting articles. However, to improve the search quality, synonyms of these keywords were also used to collect the data for this research. The keywords selected for data collection included: Cluster, Firms' agglomeration, Firms' cooperation, Firms' proximity, Internationalization, Export, and their combinations. Next, according to Martínez-Fernández et al. (2012), a 10-year time period is appropriate for a thematic review of the literature. Consequently, 260 published articles from $1 / 2009$ to $12 / 2018$ were selected using Google's advanced search at the beginning. Then, these papers were re-analysed in $\mathrm{N}$-VIVO as the qualitative analytical software to delete unrelated papers.

As for the final data selection, this paper analysed 152 papers (Appendix A), published in the top 30 journals (Figure 2), relating to the internationalization of clusters. Finally, a list of the contents of all papers was prepared. This list includes; keywords, titles, journal name, and year of publication, using the CVS format. After this, we imported the data to the software and managed them (edit, de-duplicating, and set the periods) for analysis in SciMAT. In comparison to its competitors, SciMAT is one of the most complete science mapping software (Cobo et al., 2012).

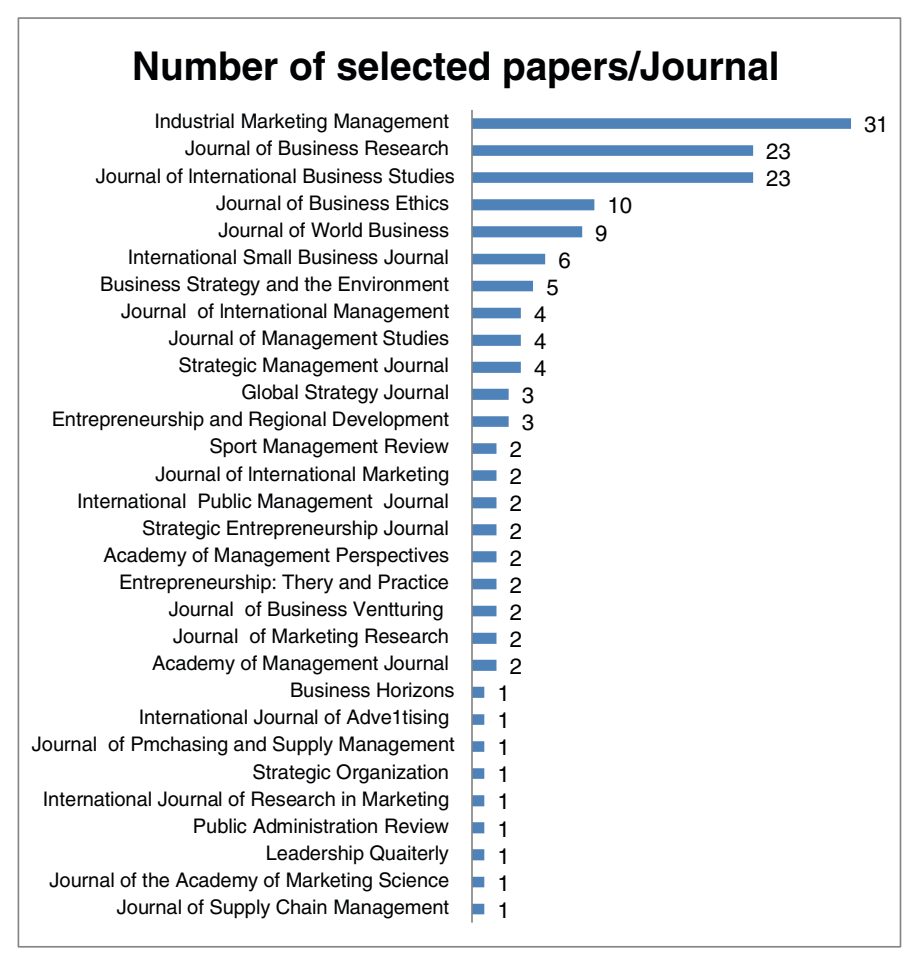

Figure 2

The top 30 publishing journals contributing to the area of cluster internationalization

Source: The authors themselves. 


\subsection{Intended keyword classification (Step 2)}

After selecting the articles and collecting the necessary information such as; author's name, year of publication, abstract, and the keywords, the next part is to complete the keyword classification. As mentioned before, the prepared file was imported into SciMAT for further corrections, categorizations, and analysis. The results were revised, and necessary corrections were made. Therefore, the duplicate keywords used in the papers were omitted in a de-duplicating process to improve the accuracy and quality of the results (Cobo et al., 2012). The keywords were then categorized into separate classes, called items. This research identified a total of 585 keywords that were categorized into 113 items. Table 1 shows an example of de-duplicating and keyword classification processes.

Table 1

De-duplicating process example

\begin{tabular}{llr}
\hline \multicolumn{1}{c}{ Before de-duplicating } & \multicolumn{1}{c}{ After de-duplicating } \\
\hline SOCIAL-NETWORKS & & SOCIAL-NETWORKS \\
SOCIAL-NETWORK- & SOCIAL- & SOCIAL-NETWORK- \\
ANALYSIS & ANALYSIS \\
FACEBOOK & NETWORKS & FACEBOOK \\
SOCIAL-NETWORK & & SOCIAL-NETWORK
\end{tabular}

Source: Cobo et al. (2012).

On the left, there is a set of keywords relating to social networks. On the right, the keywords are categorized into one class and identified as Social Networks, the process by which the 48 items are categorized as main classes. These items are cited in at least two papers. The cluster map of de-duplicated keywords is shown in Figure 3.

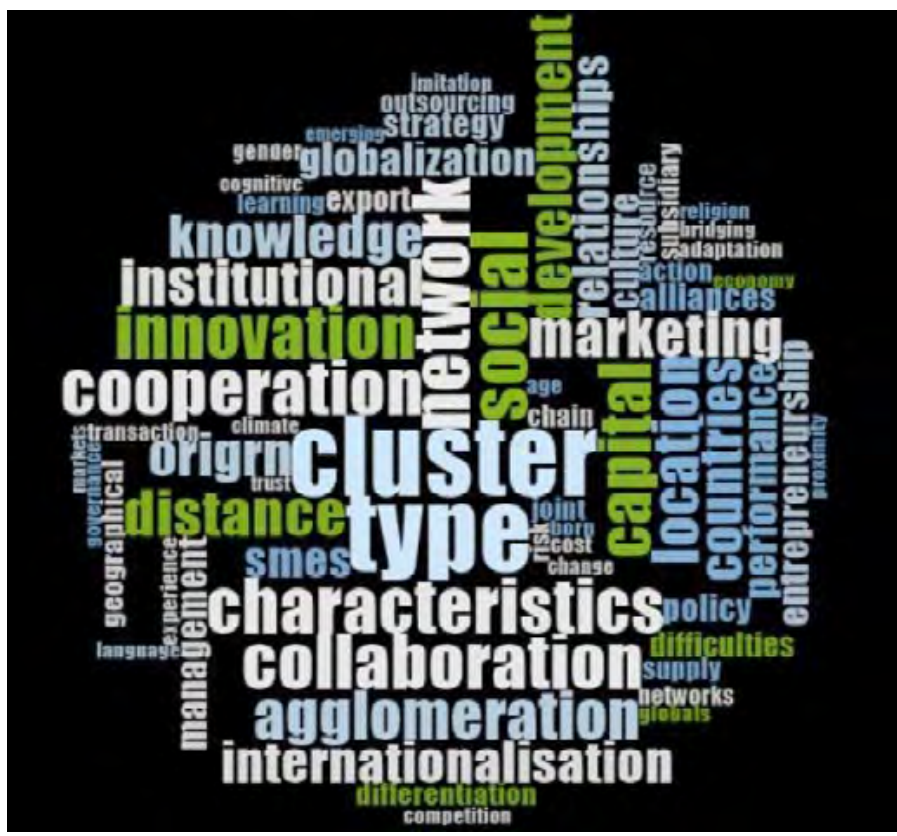

Figure 3

The cluster map of de-duplicated keywords Source: the authors themselves.

\subsection{SciMAT analysis (Step 3 to 8)}

As mentioned above, to use SciMAT, the configuration must be applied in five main steps (Figure 1). These steps contain "Time-Slicing Process", "Building the data set", "Creating and Normalizing the Networks", "Determining the Desired Algorithm", and "Performing Necessary Analyses" (Cobo et al., 2012, p. 1616). A complementary explanation is available in Table 2.

Table 2

SciMAT analysis method complementary explanation

\begin{tabular}{c|l}
\hline \multicolumn{1}{c|}{ Title } & \multicolumn{1}{c}{ Explanation } \\
\hline $\begin{array}{l}\text { A. Time-Slicing } \\
\text { Process }\end{array}$ & $\begin{array}{l}\text { Before starting the intended analyses, the } \\
\text { time-slicing process should be performed to } \\
\text { facilitate the longitudinal mapping process } \\
\text { and help researchers trace the evolutionary } \\
\text { use of keywords over time. }\end{array}$ \\
\hline
\end{tabular}

B. Building the data The data is filtered in three phases. The set $\quad$ defined time periods must be selected first. Then, with regard to the nature of the study, one item is selected among the five available items (i.e., authors, words, reference, authorsreference, and source-reference). Finally in this stage, the user has to select a number for the minimum frequency or threshold of the data for each period.

\begin{tabular}{c|l}
\hline $\begin{array}{c}\text { C. Creating the } \\
\text { Networks }\end{array}$ & $\begin{array}{l}\text { In this section, users must first select the type } \\
\text { of matrix regarding the selected unit. Then } \\
\text { the threshold edge value of the network for } \\
\text { each time period should be configured. }\end{array}$ \\
\hline $\begin{array}{l}\text { D. Normalizing the } \\
\text { Networks }\end{array}$ & $\begin{array}{l}\text { Here, one method is required to be set to } \\
\text { normalize the networks. }\end{array}$ \\
\hline $\begin{array}{l}\text { E. Determining } \\
\text { the Desired } \\
\text { Algorithm }\end{array}$ & $\begin{array}{l}\text { In this stage, the type of algorithms and the } \\
\text { maximum and minimum numbers of items } \\
\text { per cluster must be specified. }\end{array}$ \\
\hline $\begin{array}{l}\text { F. Performing } \\
\text { Necessary } \\
\text { Analyses }\end{array}$ & $\begin{array}{l}\text { In the final step, the researcher selects the } \\
\text { type of analyses to receive the final results. }\end{array}$ \\
\hline
\end{tabular}

Source: the authors themselves.

Considering the limited number of published papers each year, their annual review was not logical. Hence, in this research, we employed the minimum possible periods. Two 5-year periods were configured for the longitudinal and thematic analysis to prevent the accumulation of confusing, inaccurate, or duplicate results, and to add to the scientific value of the study. Therefore, it was decided to analyse the relevant papers published from the beginning of 2009 to the end of 2013 (the first period) and those published from the beginning of 2014 until the end of 2018 (the second period). In the next section, we first enter time returns. Then, with regard to the conceptual nature of this study, the item of Words was selected among other choices. The minimum frequency or threshold of the data was set for each period. In this case, even the single keywords that had been repeated in several papers were included in the final analysis. 
In order to create and normalize the networks, this work selected the Keyword as the unit of analysis; thus, the co-occurrence was set as the desired relation. Next, the minimum threshold edge value of the network for each time period was configured as 2. Finally, we selected the equivalence index method as the similarity measure to normalize the networks.

As mentioned in Table 2, the next stage is determining the desired algorithm. This research employed the simple centres algorithm to develop the desired maps and relevant clusters. Moreover, to better control the outputs and obtain more transparent results, the maximum and minimum number of members per cluster was set on 8 and 3, respectively.

In the final step, the following analyses were selected to be performed on the designed maps. First, "density and centrality" of the networks were measured separately in each time period. This analysis can be performed by using the default settings of the software. "Centrality" indicates the degree of integration of a network with other networks. In other words, it shows the external cohesion of the cluster, and can be defined as:

$$
\mathrm{c}=10 * \Sigma \mathrm{e} \mathrm{UV}
$$

Where "u" is an item that belongs to the cluster and "v" is an item that belongs to other clusters. "Density" indicates the degree of internal strength within a network and can be defined as:

$$
\mathrm{d}=100 \frac{\sum \mathrm{e} i \mathrm{j}}{\mathrm{n}}
$$

Where items " $i$ " and " "j" belong to the cluster and " $n$ " represents the number of items in the theme (Cobo et al., 2012, p. 1617). Subsequently, the performance of each item was measured by using different performance measures. For this purpose, the document mapper function was adjusted on the core mapper and $h$-index was selected to calculate their performance. The performance of the items will then be described in detail. Finally, the amount of overlap between the items in each period was calculated, and the evolutionary use of keywords over time was traced. Temporal analysis is what enables scholars to understand and compare the conceptual, social, and intellectual evolution of a subject over different periods. Finally, to determine the probability distributions, Jacquard's index and inclusion index were used in this section.

\section{RESULTS AND DISCUSSION}

\subsection{Initial data statistic}

Figure 4 shows the trend in the quantity of selected articles. While the collected data is related to the recent decade, the result confirms that the number of publications on the topic is growing in the second five-year period (2014-2019). The initial statistics find that 68 papers which represent approximately $45 \%$ of all collected data have been published in the last three years. In addition, $78 \%$ of these articles were published in 10 journals. Table 3 shows where and when these investigations appear. These results highlight the growing importance of internationalization in geographic economy literature.

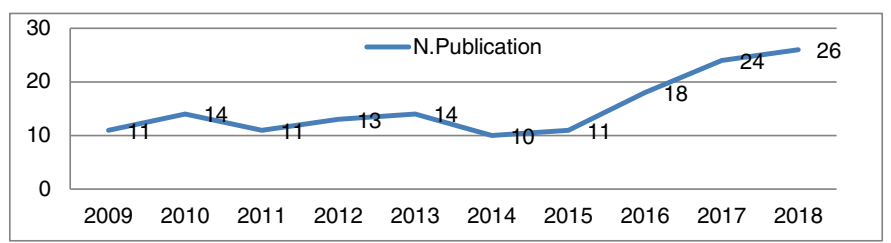

Figure 4

The evaluation of published papers from 2013-2019

Source: the authors themselves.

Table 3

\begin{tabular}{|c|c|c|c|c|c|c|c|c|c|c|c|c|c|}
\hline & JOURNAL NAME & JSR Ranking & 2009 & 2010 & 2011 & 2012 & 2013 & 2014 & 2015 & 2016 & 2017 & 2018 & TOTAL \\
\hline 1 & Industrial Marketing Management & 1.663 Q1 & 2 & 3 & 1 & 4 & 3 & 2 & 1 & 2 & 7 & 6 & 31 \\
\hline 2 & Journal of International Business Studies & 5.198 Q1 & 2 & 2 & 1 & 3 & 4 & & 3 & 2 & 2 & 4 & 23 \\
\hline 3 & Journal of Business Research & $1.260 \mathrm{Q} 1$ & 1 & & & & 5 & 4 & 2 & 4 & 3 & 4 & 23 \\
\hline 4 & Journal of Business Ethics & $1.276 \mathrm{Q} 1$ & & 1 & & 3 & & & & 3 & 1 & 2 & 10 \\
\hline 5 & Journal of World Business & $1.722 \mathrm{Q} 1$ & & & 1 & 2 & & & & 4 & 1 & 1 & 9 \\
\hline 6 & International Small Business Journal & $1.974 \mathrm{Q} 1$ & & & 1 & & & 1 & 1 & & 2 & 1 & 6 \\
\hline 7 & Business Strategy and the Environment & $1.881 \mathrm{Q} 1$ & & 1 & 1 & & & 1 & 2 & & & & 5 \\
\hline 8 & Strategic Management Journal & 8.006 Q1 & & 1 & & & & & 1 & 1 & 1 & & 4 \\
\hline 9 & Journal of Management Studies & $3.804 \mathrm{Q} 1$ & 2 & & 2 & & & & & & & & 4 \\
\hline 10 & Journal of International Management & $1.432 \mathrm{Q} 1$ & 1 & 1 & & & 1 & & & & & 1 & 4 \\
\hline
\end{tabular}

Top 10 publishing journals based on the number of publications

Source: the authors themselves.

\subsection{Keyword analysis}

According to the settings that we made in each stage of using the software, five types of analysis were applied here. First, the performance of each item was measured by its h-index. Then in each time period, the most important items in terms of density, centrality, and performance were individually identified and shown on separate diagrams. Next, the evolutionary use of items (keywords) over the two periods was traced, and finally, the overlap rate of items was determined over the two periods. 
However, the software in the set time scopes recognized a total of 29 items that are clustered and distributed. In the first 5 years, 22 items were presented in the form of 3 clusters. The identified clusters were named after their central items. The three clusters: Network (8 items), Location and distance (8 items), and Global (6 items), were identified in the first period (see Table 4$)$. In the second period, 24 items were also identified and presented in the form of 3 clusters: Cluster type (8 items), Development (8 items), and Social capital (8 items). Table 5 shows all mentioned information.

Table 4

Analytical information related to the first 5 years (2009-2013)

\begin{tabular}{|c|c|c|c|c|c|c|}
\hline \multicolumn{7}{|c|}{ Cluster content, $h$-index, centrality and density in the first time scope (2009-2013) } \\
\hline Cluster name & Items content & h-index & Centrality & C- range & Density & D-range \\
\hline Networks & $\begin{array}{l}\text { Cluster type; Network; Institution } \\
\text { characteristics; Social capital; Knowledge; } \\
\text { Marketing; Entrepreneurship; Social } \\
\text { networks }\end{array}$ & 22 & 22.95 & 1 & 13.05 & 0.67 \\
\hline Location and distance & $\begin{array}{l}\text { Location-and-distance; Innovation; } \\
\text { Agglomeration; Cooperation; location } \\
\text { and distance; Management; SMEs; } \\
\text { Relationships; Resources }\end{array}$ & 14 & 13.69 & 0.67 & 13.41 & 1 \\
\hline Global & $\begin{array}{l}\text { Internationalization; Global; } \\
\text { Development; Strategy and policy; } \\
\text { Countries of origin; Outsourcing }\end{array}$ & 9 & 9.97 & 0.33 & 10.03 & 0.33 \\
\hline
\end{tabular}

Source: the authors themselves.

Table 5

Analytical information related to the second 5 years (2014-2018)

\begin{tabular}{|c|c|c|c|c|c|c|}
\hline \multicolumn{7}{|c|}{ Cluster content, $h$-index, centrality and density in the second time scoop (2014-2018) } \\
\hline Cluster name & Items content & h-index & Centrality & C- range & Density & D-range \\
\hline Cluster type & $\begin{array}{l}\text { Cluster type; Cooperation; Innovation; } \\
\text { Relationships; SMEs; Institution } \\
\text { characteristics; Performance; Climate } \\
\text { change }\end{array}$ & 16 & 30.1 & 0.67 & 13.28 & 1 \\
\hline DEVELOPMENT & $\begin{array}{l}\text { Development; Internationalization; } \\
\text { Global; Differences; Experience; Supply } \\
\text { chain; Risk }\end{array}$ & 14 & 19.14 & 0.33 & 11.13 & 0.67 \\
\hline SOCIAL-CAPITAL & $\begin{array}{l}\text { Social capital; Network; Marketing; } \\
\text { Location and distance; Agglomeration; } \\
\text { Knowledge; Difficulties; Management }\end{array}$ & 11 & 32.34 & 1 & 10.53 & 0.33 \\
\hline
\end{tabular}

Source: the authors themselves.

\section{A. Cluster performance}

The performance of each item (de-duplicated keywords) was measured based on its h-index.

In general, the h-index is an indicator to calculate the impact factor (Liu \& Rousseau, 2008). This research defined the h-index as the maximum value of the number that the given item has used in $\mathrm{h}$ (the number of papers) that has each been cited at least $\mathrm{h}$ time. Accordingly, the software recognized 29 items as the most impacted, and repeated the keyword group that is shown in appendix A2.

These items, based on their h-index, appear in the form of clusters in each time scope. In the first 5 years, the cluster with the centrality of Network had the highest h-index (equal to 22). The result confirms the importance of these items in studies conducted in the first period. The clusters, with the centrality of Location and distance (h-index $=14$ ) and Global (h-index $=8$ ) were identified and presented as other important clusters, respectively (Figure 5 ). In the second period, the obtained h-index values were slightly different, as the item clusters with the centrality of Cluster-type (h-index $=16)$, Social-capital (h-index $=14)$, and Development $(\mathrm{h}$-index $=11$ ), were identified as the most important clusters, respectively (Figure 6). In the second time scope, we found more items, and this highlights the requirement of the research expansion in this area. 


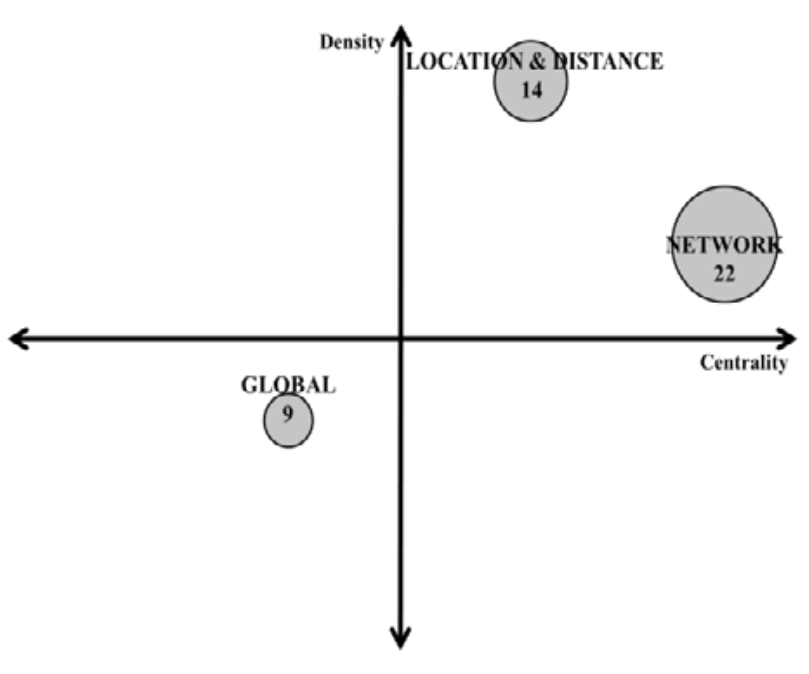

Figure 5

Strategic diagram (h-Index) period (2009-2013)

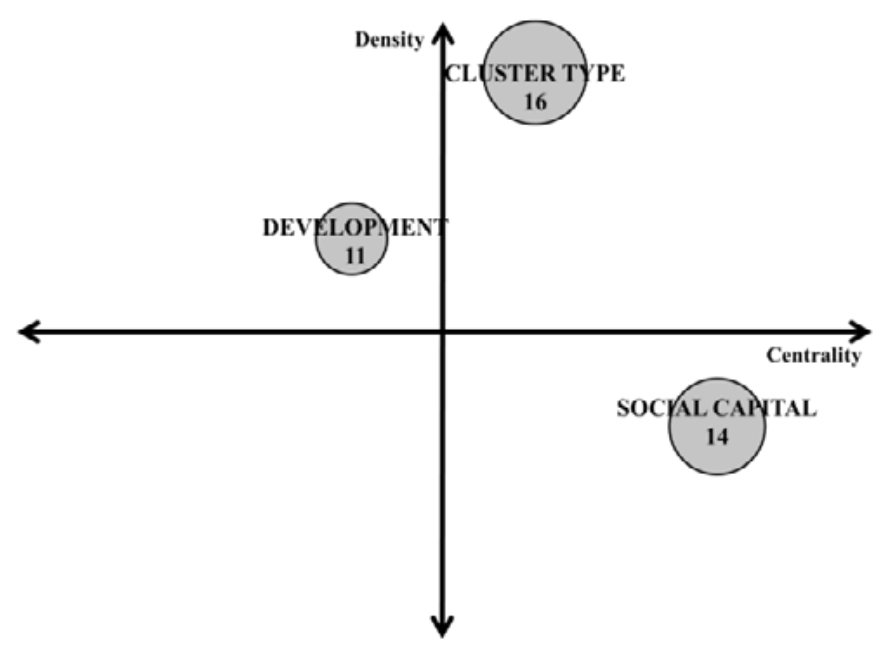

Figure 6

Strategic diagram (h-Index) period (2014-2018)

\section{B. Centrality of Clusters}

In this section, we discussed the centrality of each cluster and its items. In the first 5-year period, Network, Location and Distance, and Global, had the highest rates of centrality, respectively (Table 4). This means that the keywords used in the constituent items of Network, had the highest frequency both within the cluster, and, in comparison to the keywords belonging to other clusters. In the second period, the cluster of Social-capital had the highest centrality value. This means that the keywords used in the constituent items of this cluster had the highest frequency both within the cluster and in comparison to the keywords belonging to other clusters. Cluster type and Development were ranked next in terms of centrality values, respectively (Table 5).

\section{Density of Clusters}

Here we discussed the density of items and their relationship in selected articles. The results of this section reveal the core of academic attention on this topic, during each period of time. In the first period, the cluster with the centrality of Location and Distance had the highest internal strength, whereas the Network and Global clusters were ranked next in terms of density values. In the second time period, all clusters had stronger and more diverse internal relations compared with the previous period. In this period, the Cluster-type cluster had the highest internal strength and the Innovation and Social-capital clusters ranked second and third in terms of density values (see Table 4 and 5).

The 1st Cluster in the first time period: The item of Location and Distance is located in the core of the densest cluster of this time scope. This item has a relationship with all 7 other items of the cluster. Other items such as Innovation, Agglomeration, and Cooperation followed this item in this issue. The strongest relationships are between Management with Relationship, and Resource with Location. Figure 7 shows all relationships in this cluster group.

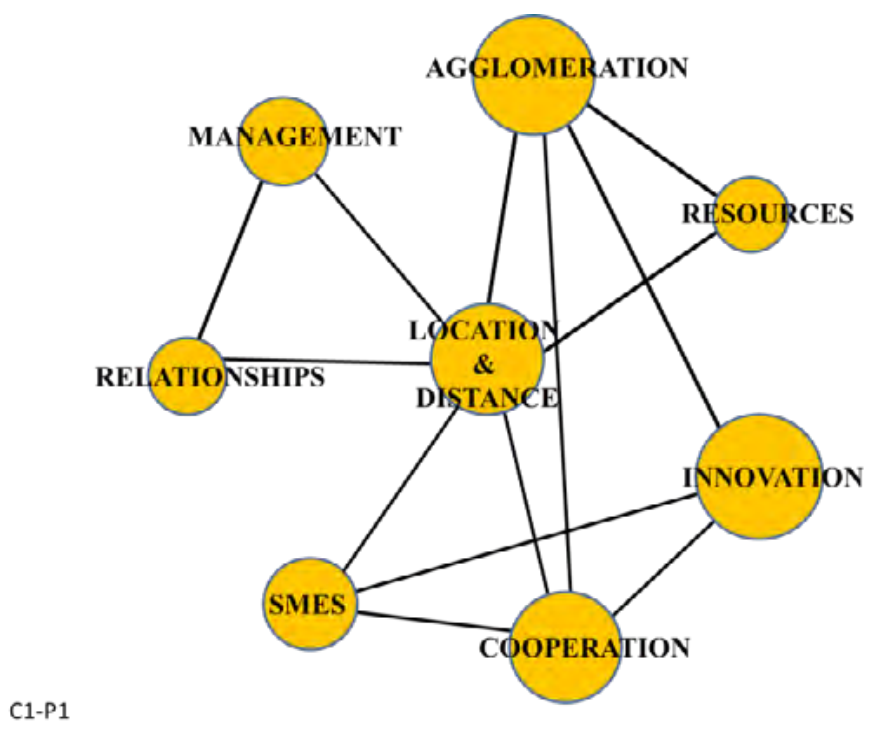

Figure 7

Cluster 1 - Period 1 (2009-2013)

The 2nd Cluster in the first time period: In terms of density, during this period, the item Network is located in the core of the second ranked cluster. It means that, the keywords belonging to this item had more effective relations with other keywords in this cluster. In addition, following the strong relationship between the items of Networks with Social-networks, the Institution-characteristics had strong relationships with the items of Marketing and Knowledge. Figure 8 depicts other relationships in this cluster. 


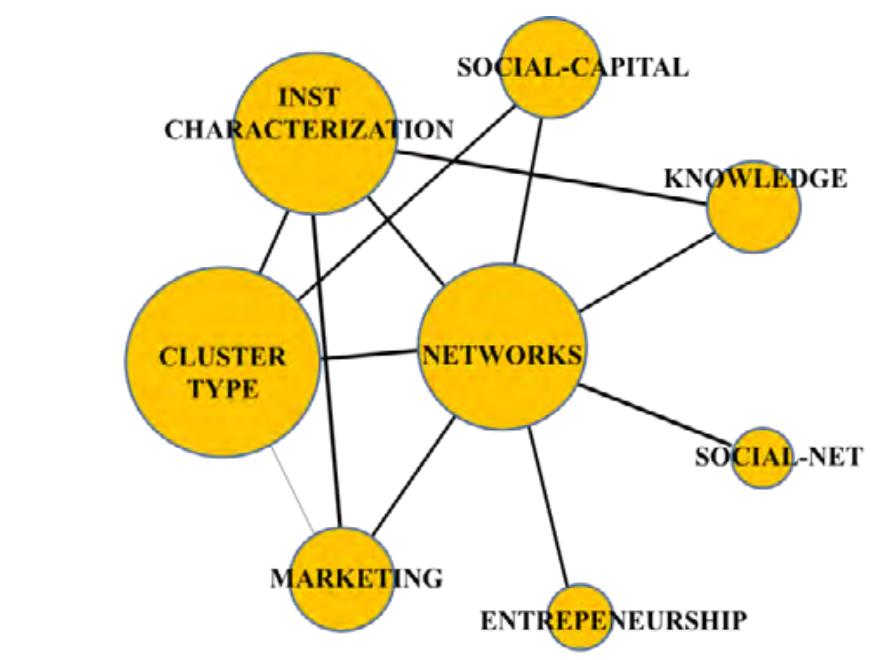

Figure 8

Cluster 2 - Period 1 (2009-2013)

The 3rd Cluster on the first time period: Finally, Global is the third cluster in terms of density value. The item of Global is in the centre, but the strongest relationship is between Internationalization, and, Strategy and Policy. The rest of the connected items are presented in Figure 9.

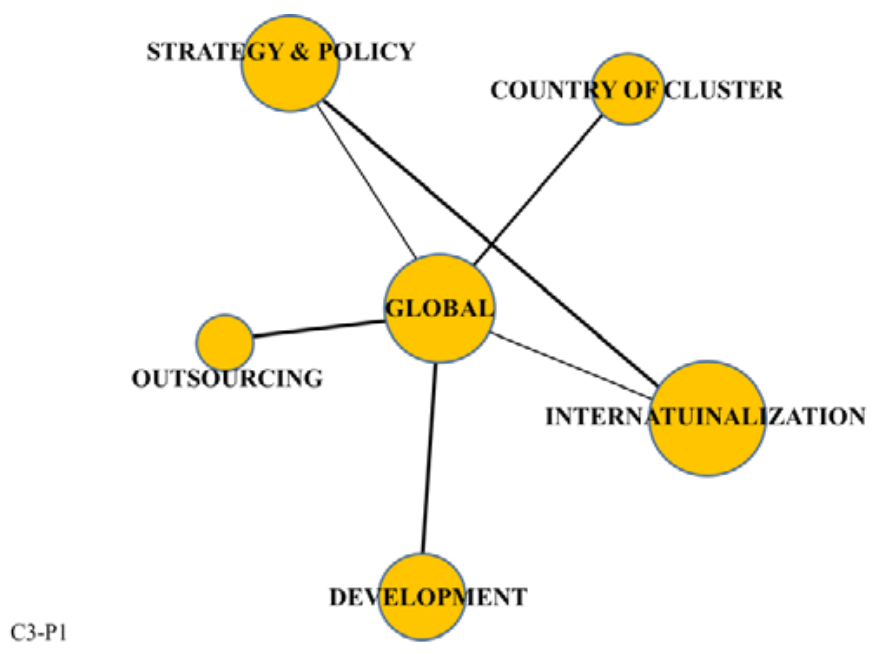

Figure 9

Cluster 3 - Period 1 (2009-2013)

The $1^{\text {st }}$ Cluster in the second time period: In the second period, the item of Cluster type is in the core of the densest clusters. As it appears in Figure 10, this item is connected with Cooperation, Innovation, Relationships, SMEs, Institution characteristics, Performance, and Climate-change. Following the core item, the items of Innovation and Cooperation had the highest number of relations with the rest. The strongest relationships in this cluster belong to Cluster-types with Cooperation and Performance, and Innovation with Inst-Characteristics. In addition, we have the emergence of new items such as Climate-change and their relationship with the item of Cluster-type. These results indicate the importance of these items in recent times.

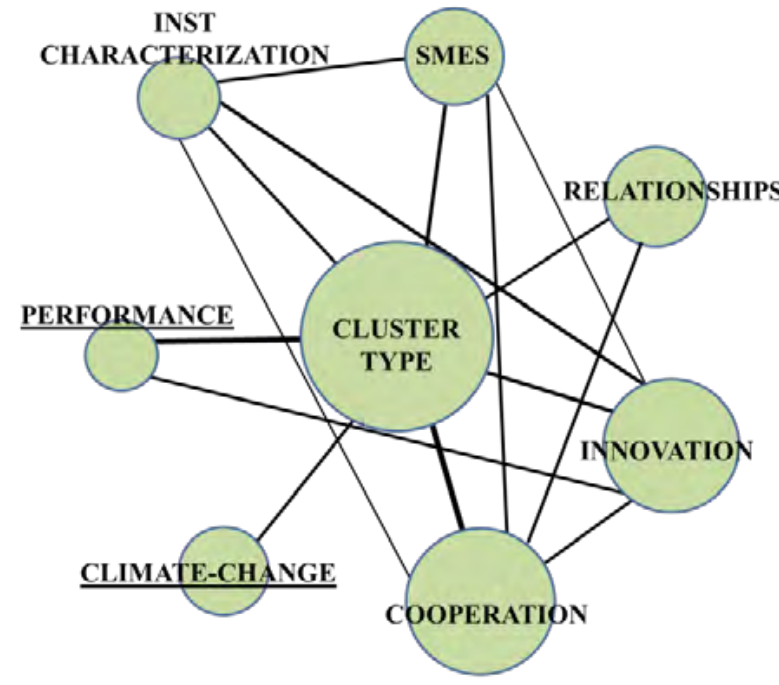

Figure 10

Cluster 1 - Period 2 (2014-2018)

The 2nd Cluster in the second time period: In this time scope, the cluster of Development ranked second in terms of density value. Seven other items including Countries of origin, Internationalization, Global, Differences, Experience, Supply chain, and Risk surrounded Development. The diagram's lines in Figure 11 show that the item Internationalization is second in terms of the number of relations with other members of the cluster. What makes it interesting is the strong relationship between Risk and Development, Experience and Internationalization, and Global with the Development.

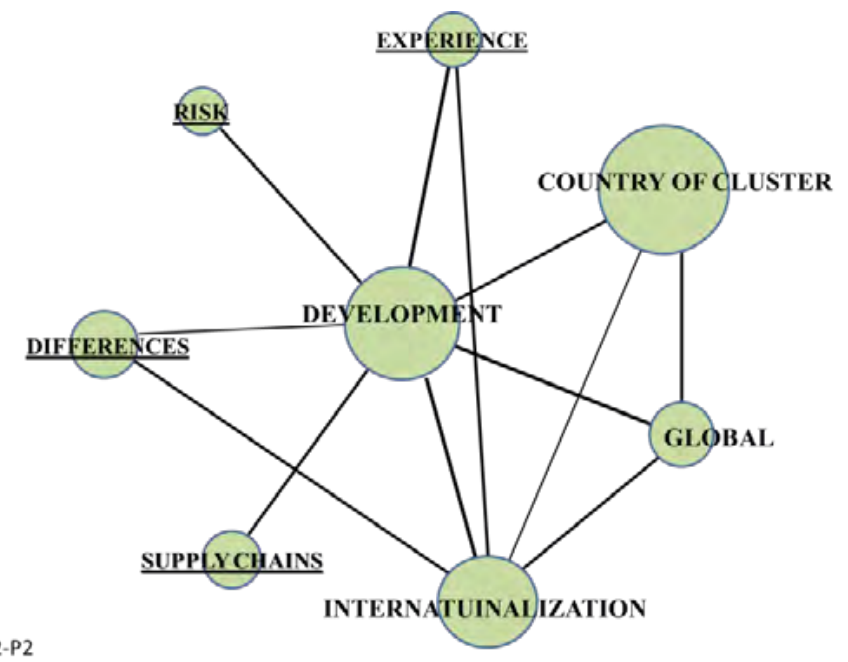

Figure 11

Cluster 2 - Period 2 (2014-2018)

The 3rd Cluster in the second time period: Finally, the cluster with the centrality of Social Capital ranked as the third and last cluster in terms of density value in the second period. All connections between items appeared in Figure 12. Logically, Social Capital as the central item is connected with all other items in this cluster. Other results in this picture show that researchers 
focused on the role of Marketing in locations, the relationship between Management and Difficulties, and the item of Networks with Location, Agglomeration, and Knowledge.

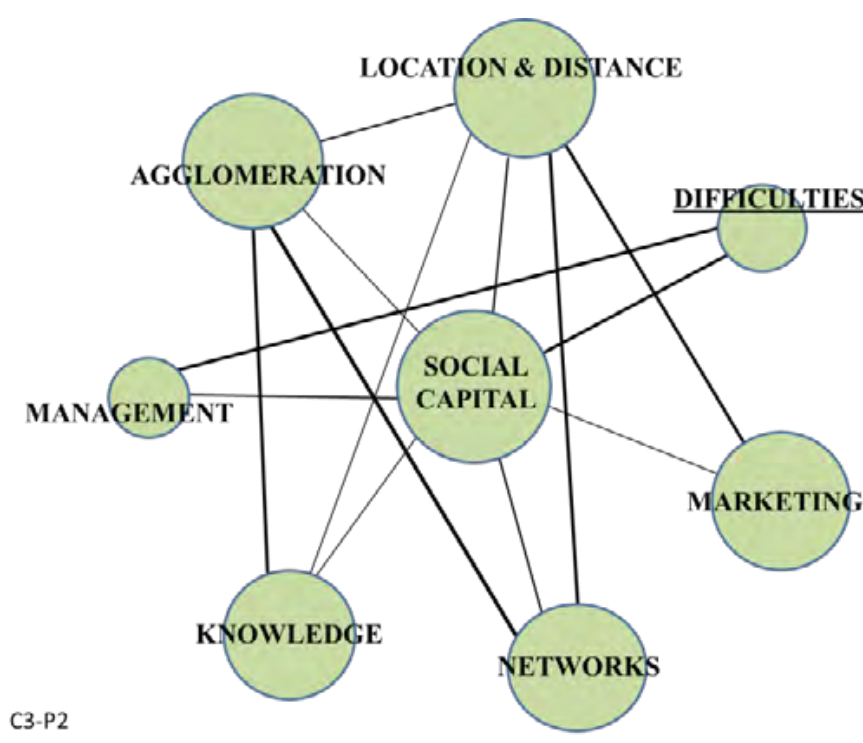

Figure 12

Cluster 3 - Period 2 (2014-2018)

\section{The EVolution PROCess}

The evolution map illustrates the update of studies and changes related to the use of keywords, through temporal or longitudinal analysis of papers as shown in Figure 13. In temporal or longitudinal analysis, the size of a circle (representing a cluster) indicates the number of published documents associated with that cluster (Cobo et al., 2012). The size of the circle representing factors used in the first period was smaller than that of those used in the second period; and for this reason, a higher number of papers had been published in the second period. The map also depicts changes in the composition of each cluster's items over the two studied periods. First, the cluster called Network in the first period was disintegrated and its constituent items became parts of the other clusters, Cluster-type and Social Capital, in the second period. These changes are represented by solid lines; however, the line that connects Network to the Social Capital is bolder than the one between Network and Cluster-type. This indicates that a larger list of keywords belonging to the Network cluster has been shared with the Social Capital cluster in the second period. The second change, was the transfer of items belonging to the Location and Distance cluster in the first period to Social Capital, and Cluster-type clusters in the second period. The solid line between the Location and Distance and Social Capital clusters means that the former has shared its main keywords with the Social Capital cluster. However, the dotted line connecting Location and Distance to Cluster-type indicates that the main keywords have not been shared in the second period. The third case, was the integration of items belonging to the Global cluster, in the first period, and into the Development cluster in the second period. The boldest line represents this change, and this indicates that many keywords have been repeated during this process.

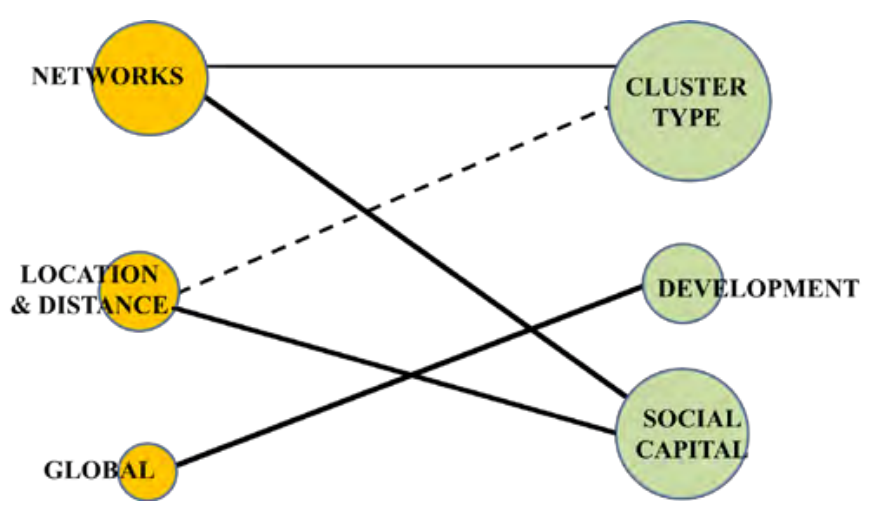

Figure 13

The evolution Area map

\section{E. Overlapping MAP}

Figure 14 shows the diagram of overlapping items in two consecutive periods. The circles represent the time periods and the number within the circles shows the number of items in each period. In this study, a total of 585 keywords were identified and categorized into 113 items. In total, 62 and 94 items were used in the first and second periods, respectively. The horizontal axis represents the number of items shared by the two periods $(\mathrm{n}=43)$. The stability index between the items was 0.69 . The downward axis represents the number of new items in the second period $(n=51)$, whereas the upward axis shows 19 items that were only used in the first period.

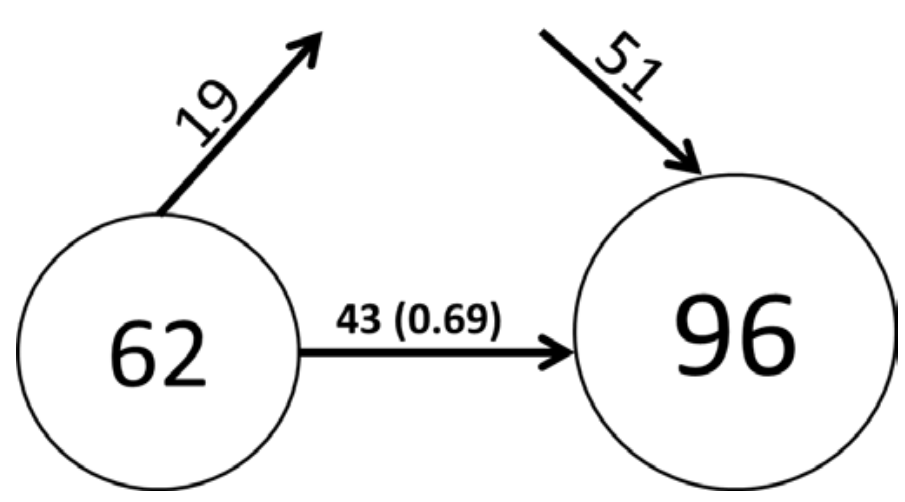

Figure 14

The overlapping-items diagram

\section{CONCLUSIONS}

As Boschma (2005) stated, firms' flexibility and their contact with the outside are some of the best solutions for the disadvantages of multidimensional proximity (i.e. isolation and lock-in). Maintaining the connection with international markets, in addition to overcoming local constraints such as limited resources and small markets (Porter, 2000), can ensure access to new knowledge and innovation (Boschma, 2005). Therefore, the 
topic of cluster internationalization has become an increasingly popular topic for advanced countries' cluster associations, for instance the European Cluster Collaboration Platform (ECCP) (ECCP, 2021). However, as the findings of this study suggest, little is known about the access of local clusters to larger markets. Therefore, a review of the available literature can provide researchers with a better insight into relevant research on this topic (González-Torres et al., 2020). In this regard, and among several methods, the bibliometric analysis has received more attention by academics (Muñoz-Leiva et al., 2012). As a qualitative method, bibliometric mapping can examine various parts of the available literature such as content of articles, authors, citations, or keywords (Cobo et al., 2012).

Regarding the first research question, a total of 584 keywords (categorized into 48 main items) were collected from 152 papers, published in the top 30 relevant journals over the 10 -year time period from 2009 to 2018 (Appendix A2). The items were then analysed in terms of performance, centrality, density, evolution, overlapping, and information about the level of use of the keywords, in SciMAT during the two periods (1/2009-12/2013 and $1 / 2014-1 / 2019)$. The result confirms, among all techniques, that bibliometric analysis is a qualitative method that creates realistic viewpoints about the content and structure of a research topic (Ding et al., 2001; Weismayer \& Pezenka, 2017), with particular regard to keyword bibliometric analysis (Muñoz-Leiva et al., 2012).

Based on the h-index of each item, the result highlights the importance of each cluster (group of items) from each time period. Items located in the clusters such as Network (h-index 22), Location and Distance $(\mathrm{h}$-index $=14)$, and Global $(\mathrm{h}$-index $=8)$, lost their importance to the items that were located in Cluster-type (h-index $=16)$, Social-capital $(\mathrm{h}$-index $=14)$, and Development $(\mathrm{h}$-index $=11$ ), clusters from the second time period. From these items, we can name Outsourcing, Risk, Social networks, Experience, and Climate change. Although, they only made up a small number of keywords and were used in few papers, they have a high h-index and are recognized as frequently used items. Therefore, it can be concluded that more attention should be paid to these items in future research.

However, the calculation of the centrality and density of items as clusters, and the items' relationships is the second objective of this research. Before answering the second question, the general statistics obtained from the most frequently used keywords are: 22 items were presented in the form of 3 clusters in the first period. In the second time period, 5 of these 22 items were omitted, and 7 new items were added. Therefore, in the second period, 24 items were presented within three new clusters.

In terms of centrality and in specific reference to the first five years, items agglomerated in the cluster of Network (i.e. Network, Social Capital, Institutional Characteristics, Cluster-type, Marketing, Entrepreneurship, Social Network, and Knowledge) were of principal importance to the research. Items located in the clusters of Location-distance (i.e. Location and Distance, Agglomeration, Management, Relationships, SMEs, Cooperation, Innovation, and Resources) and Global (i.e. strategy-policy, outsourcing, development, internationalization, and country of clusters) were following the network cluster. Regarding the density, however, the use of those items was slightly different. Items agglomerat- ed around Location-distance had more density than those items which were located in clusters of Network and Global.

The results reveal that the density/centrality of items and their location in clusters completely changed in the second time period. A new cluster named "cluste- type" surrounded by items (i.e. cooperation, innovation, relationships, SMEs, institutional characteristics, climate-change, and performance) is the first in the density and second in the centrality of the selected research. On the other hand, items located in the cluster called social capital (i.e. Social Capital, Location-distance, Agglomeration, Management, Knowledge, Network, Marketing, and Difficulties) won the first position in the terms of research centrality, but had the third position in the density, and was located after the cluster named Development. The item of "Development", along with 7 more items (i.e. Country of Clusters, Experience, Risk, Differences, Supply Chain, Internationalization, and Global) has the second place in density and the third in centrality.

To summarise, the relationship between items shows that, in the first five years, researchers have emphasized the importance of location and management to create collaboration and innovation, especially in small businesses. Subsequently, the relationships between keywords in the second cluster, highlight the role of networking in knowledge creation, marketing, and social relationships. The last cluster in this period, shows that items such as Development or Internationalization have been used to under-shadow the item Global.

In the second time period, the change in the researchers' priority can be clearly understood from the use of the keywords. In this period, more importance had been given to the type of clusters, and their relationship, with items such as Cooperation, Innovation, Performance, Characteristic, and most interestingly Climate Change. In the second 5-year period, all items of the third cluster from the first period gain more importance and are replaced in the second cluster. The item of Global gives way to its core position by Development. This means that academics have focused more on cluster development than on globalization. From the density of items, it can be understood that this development has depended on internationalization, size, experiences, country of cluster, and other differences. The last cluster in this period depicts important items such as; Social Capital, Networks, Knowledge, Marketing, Management, and Firms' Proximity as the subjects of today's research. However, from the density and centrality of these keywords, it can be understood that these items need more attention in future investigations.

The result of the evolution process map highlights the change of focus and development for researchers. It confirms that general topics are replaced by more detailed subjects. For instance, the central items such as, Location and Network, in the second period gave their places to Social Capital. Or the items that were used in the first period alongside Global appeared in the cluster of Development in the second period. Thus, it can be concluded that today, investigations on this topic are focusing more on Cluster-type, Development, and Social-Capital.

In addition to all of the above, the results confirmed that items such as Cooperation, Social Capital, Marketing, SMEs, Climate Change, and different types of performances, have recently received more attention by authors, but the number of papers on each topic reveals the true lack of investigation. 


\section{LIMITATIONS AND SUGGESTIONS FOR FUTURE STUDIES}

There are several limitations that reduce the quality of bibliometric analysis. The most challenging part is the data collection. Although, in this research we have made every effort to carefully select the articles, due to the high number and variety of papers, bibliometric studies can be challenging due to some data being ignored. On the other hand, not all investigations are valid, and certain criteria must be considered to select articles. Therefore, researchers should consider that the academic level of a selected journal has an important role in research validation (Weismayer \& Pezenka, 2017). We selected the data based on SJR ranking and checked their Journal Citation Report (JCR) ranks, but there are other sources such as WOS (Web of Science) and JCR that may provide more accurate information. However, every day, top journals are publishing new papers and such investigations need to be repeated. Therefore, for future investigation it is recommended to employ a mix of sources.

Furthermore, it should be highlighted that this study is only the first step in the identification of factors affecting the cluster internationalization process, and further research is required to describe the presented items in detail. In addition, this study only analysed the keywords in terms of their placement within papers. There are many other methods, such as reviewing models, methodologies, authors' citations, which could be the subject of future investigations. Furthermore, theoretical models must be designed and tested in real-world environments to better perceive the interplay of these effective factors.

Finally, despite the high accuracy of the software, there are other, new items, that have not been recognized. These keywords can be used in or become the subject of future conceptual or theoretical investigations. For instance, keywords such as Alliances, Born Global, Bridging, Joint-action, and Imitation are new to the subject and need more research.

\section{REFERENCES}

Boschma, R. (2005). Proximity and innovation: a critical assessment. Regional studies, 39(1), 61-74. DOI: 10.1080/0034340052000320887

Brink, T. (2018). Organising of dynamic proximities enables robustness, innovation and growth: The longitudinal case of small and medium-sized enterprises (SMEs) in food producing firm networks. Industrial Marketing Management, 75, 66-79. DOI: 10.1016/j.indmarman.2018.04.005

Cobo, M. J., López-Herrera, A. G. \& Herrera-Viedma (2012). SciMAT: A new science mapping analysis software tool. Journal of the American Society for Information Science and Technology, 68(3), 16091630. DOI: $10.1002 /$ asi.22688

Cobo, M. J., López-Herrera, A. G., Herrera-Viedma, E. \& Herrera, F. (2011). Science mapping software tools: Review, analysis, and cooperative study among tools. Journal of the American Society for information Science and Technology, 62(7), 1382-1402. DOI: 10.1002/asi.21525

Coimbra, D. R., Dominsk, F. H., Correia, C. K. \& Andrade, A. (2019). Scientific production in Sports Science Journals: bibliometric analysis. Revista Brasileira de Medicina do Esporte, 25, 88-93. DOI: 10.1590/1517-869220192501208554

Ding, Y., Chowdhury, G. \& Foo, S. (2001). Bibliometric cartography of information retrieval research by using co-word analysis. Informa- tion processing \& management, 37(6), 817-842. DOI: 10.1016/S03064573(00)00051-0

ECCP (2021). European Cluster Collaboration Platform. [Online] Availableat:https://clustercollaboration.eu/tags/internationalisation [Accessed 3 November 2021].

Fahimnia, B., Sarkis, j. \& Davarzani, H. (2015). Green supply chain management: A review and bibliometric analysis. International Journal of Production Economics, 162, 101-114. DOI: 10.1016/j. ijpe.2015.01.003

Geldes, C., Felzensztein, C., Turkina, E. \& Duran (2015). How does proximity affect interfirm marketing cooperation? A study of an agribusiness cluster. Journal of Business Research, 68(2), 263-272. DOI: 10.1016/j. jbusres.2014.09.034

González-Torres, T., Rodríguez-Sánchez, J. L., Montero-Navarro, A. \& Gallego-Losada, R. (2020). Visualizing research on industrial clusters and global value chains: a bibliometric analysis. Frontiers in Psychology, 11, 1754. DOI: 10.1016/j.jbusres.2014.09.034

Janney, J. J. \& Gove, S. (2011). Reputation and corporate social responsibility aberrations, trends, and hypocrisy: Reactions to firm choices in the stock option backdating scandal. Journal of Management Studies, 48(7), 1562-1585. DOI: 10.1111/j.1467-6486.2010.00984.x

Jia, L., Li, S., Tallman, S. \& Zheng, Y. (2017). Catch-up via agglomeration: A study of township clusters. Global Strategy Journal, 7(2), 193-211. DOI: $10.1002 /$ gsj. 1154

Juliani, F., \& de Oliveira, O. J. (2016). State of research on public service management: Identifying scientific gaps from a bibliometric study. International Journal of Information Management, 36(6), 1033-1041. DOI: 10.1016/j.ijinfomgt.2016.07.003

Liao, . T. J. (2010). Cluster and performance in foreign firms: The role of resources, knowledge, and trust. Industrial Marketing Management, 39(1), 161-169. DOI: 10.1016/j.indmarman.2008.08.003

Liu, Y. \& Rousseau, R. (2008). Definitions of time series in citation analysis with special attention to the h-index. Journal of Informetrics, 2(3), 202-210. DOI: 10.1016/j.joi.2008.04.003

Martínez-Fernández, M. T., Capó-Vicedo, J. \& Vall (2012). The present state of research into industrial clusters and districts. Content analysis of material published in 1997-2006. European Planning Studies, 20(2), 281-304. DOI: 10.1080/09654313.2012.650906

Mojgani, P., Jalali, M. \& Keramatfar, A. (2020). Bibliometric study of traumatic brain injury rehabilitation. Neuropsychological rehabilitation, 1-18. DOI: 10.1080/09602011.2020.1796714

Muñoz-Leiva, F., Viedma-del-Jesús, M. I., Sánchez-Fernández, J. \& López-Herrera, A. G. (2012). An application of co-word analysis and bibliometric maps for detecting the most highlighting themes in the consumer behaviour research from a longitudinal perspective. Quality \& Quantity, 46(4), 1077-1095. DOI: 10.1007/s11135-011-9565-3

Niñerola, A., Sánchez-Rebull, M. V. \& Hernández-Lara, A. B. (2019). Tourism research on sustainability: A bibliometric analysis, Sustainability, 11(5), 1377. DOI: 10.3390/su11051377

Porter, M. (1998). Clusters and the new economics of competition. Boston: Harvard Business Review.

Porter, M. E. (2000). Location, competition, and economic development: Local clusters in a global economy. Economic development quarterly, 14(1), 15-34. DOI: 10.1177/089124240001400105

Üsdiken, B. \& Pasadeos, Y. (1995). Organizational analysis in North America and Europe: A comparison of co-citation networks. Organization studies, 16(3), 503-526. DOI: 10.1177/017084069501600306

Watson IV, . G. F., Weaven, S., Perkins, H. \& Sardana (2018). International market entry strategies: Relational, digital, and hybrid approaches. Journal of International Marketing, 26(1), 30-60. DOI: 10.1509/jim.17.0034

Weismayer, C. \& Pezenka, I. (2017). Identifying emerging research fields: a longitudinal latent semantic keyword analysis. Scientometrics, 113(3), 1757-1785. DOI: 10.1007/s11192-017-2555-z 


\section{APPENDIX A1}

List of selected articles

ID Reference

1 https://doi.org/10.1016/j.smr.2016.10.009

2 https://doi.org/10.1016/j.indmarman.2013.03.012

3 https://doi.org/10.1016/j.leaqua.2011.02.008

4 https://doi.org/10.1016/j.intman.2013.03.011

5 https://doi.org/10.5465/amj.2016.0601

6 https://doi.org/10.1057/jibs.2010.28

7 https://doi.org/10.1080/10967494.2010.524836

8 https://doi.org/10.1016/j.indmarman.2014.10.010

9 https://doi.org/10.1002/bse.694

10 https://doi.org/10.1016/j.jbusres.2018.10.029

11 https://doi.org/10.1509/jim.11.0023

12 https://doi.org/10.1057/palgrave.jibs.8400056

13 https://doi.org/10.1111/j.2042-5805.2013.01060.x

14 https://doi.org/10.1111/j.1540-6520.2009.00307.x

15 http://dx.doi.org/10.1016/j.indmarman.2013.04.003

16 http://dx.doi.org/10.1002/gsj.1154

17 http://dx.doi.org/10.1057/jibs.2015.28

18 https://doi.org/10.1002/bse.1762

19 https://doi.org/10.1016/j.indmarman.2008.08.003

20 https://doi.org/10.1007/s10551-010-0561-7

21 https://doi.org/10.1080/08985620801886513

22 https://doi.org/10.1057/jibs.2011.53

23 http://dx.doi.org/10.1016/j.indmarman.2016.06.011

24 https://doi.org/10.1016/j.indmarman.2018.01.013

25 https://doi.org/10.1007/s10551-011-1027-2

26 http://dx.doi.org/10.1016/j.jbusvent.2017.10.003

27 http://doi.org/10.1057/jibs.2009.10

28 http://doi.org/10.1057/jibs.2011.40

29 https://doi.org/10.1016/j.jwb.2017.12.001

30 http://dx.doi.org/10.1016/j.smr.2017.05.005

31 https://doi.org/10.1080/08985626.2010.488405

32 https://doi.org/10.1177/0266242612456571

33 https://doi.org/10.1080/02650487.2015.1009348

34 https://doi.org/10.1016/j.jwb.2011.04.014

35 https://doi.org/10.1016/j.jbusres.2017.12.006

36 http://dx.doi.org/10.1016/j.jbusres.2013.11.006

37 https://doi.org/10.1007/s10551-014-2373-7

38 http://dx.doi.org/10.1016/j.indmarman.2016.06.012

39 https://doi.org/10.1016/j.indmarman.2012.06.007

40 http://dx.doi.org/10.1002/smj.2679

41 http://dx.doi.org/10.1016/j.indmarman.2016.07.002

42 http://dx.doi.org/10.1002/bse.1846

43 http://dx.doi.org/10.1002/bse.1817

$44 \mathrm{http}: / / \mathrm{dx}$.doi.org/10.1016/j.indmarman.2010.06.008

45 http://dx.doi.org/10.1016/j.indmarman.2010.10.003

46 https://doi.org/10.1177/1476127010374251

47 http://dx.doi.org/10.1016/j.jbusres.2014.09.025

48 https://doi.org/10.1016/j.intman.2010.09.007

49 https://doi.org/10.1002/sej.1247

50 https://doi.org/10.1016/j.jbusres.2017.11.044

51 https://doi.org/10.1057/s41267-018-0153-9

52 http://dx.doi.org/10.1016/j.indmarman.2016.07.007

53 http://dx.doi.org/10.1016/j.bushor.2009.06.001
54 https://doi.org/10.1057/s41267-017-0086-8

55 http://dx.doi.org/10.1057/jibs.2012.33

56 http://dx.doi.org/10.1007/s10551-012-1378-3

57 https://doi.org/10.1177/0266242617740412

58 http://dx.doi.org/10.1016/j.jbusres.2016.04.092

59 http://dx.doi.org/10.1016/j.jbusres.2014.09.034

60 http://dx.doi.org/10.1016/j.jbusres.2016.04.068

61 http://dx.doi.org/10.1002/gsj.1167

62 http://dx.doi.org/10.1016/j.indmarman.2011.04.003

63 http://dx.doi.org/10.1057/jibs.2013.16

64 http://dx.doi.org/10.1057/s41267-016-0006-3

65 https://doi.org/10.1016/j.jbusres.2018.07.010

66 http://dx.doi.org/10.1007/s10551-014-2372-8

67 http://dx.doi.org/10.1016/j.indmarman.2008.12.006

68 http://dx.doi.org/10.1016/j.jbusres.2013.02.026

69 http://dx.doi.org/10.1016/j.jbusres.2012.02.043

70 http://dx.doi.org/http://dx.doi.org/10.1016/j.jbusres.2013.11.005

71 http://dx.doi.org/10.1016/j.jbusres.2013.02.032

72 http://dx.doi.org/10.1002/smj.841

73 http://dx.doi.org/10.1002/bse.688

74 http://dx.doi.org/10.1016/j.intman.2016.07.002

75 http://dx.doi.org/10.1016/j.jwb.2015.11.007

76 https://doi.org/10.1111/j.1540-6210.2008.01972.x

77 http://dx.doi.org/10.1002/sej.1174

78 http://dx.doi.org/10.1509/jim.17.0034

79 http://dx.doi.org/10.1016/j.jbusres.2013.07.002

80 http://dx.doi.org/10.1016/j.indmarman.2013.07.013

81 http://dx.doi.org/10.1177/0266242611402565

82 http://dx.doi.org/10.1016/j.indmarman.2011.06.011

83 http://dx.doi.org/10.1007/s10551-011-1104-6

84 http://dx.doi.org/10.1016/j.intman.2008.02.003

85 http://dx.doi.org/10.1016/j.jwb.2010.10.026

86 http://dx.doi.org/10.1016/j.jbusres.2015.10.050

87 http://dx.doi.org/10.1007/s10551-015-2554-z

88 http://dx.doi.org/10.1057/jibs.2008.85

89 http://dx.doi.org/10.1057/jibs.2014.70

90 http://dx.doi.org/10.1016/j.indmarman.2014.04.013

91 http://dx.doi.org/10.1057/jibs.2013.42

92 http://dx.doi.org/10.1057/s41267-017-0105-9

93 http://dx.doi.org/10.1016/j.indmarman.2010.06.007

94 https://doi.org/10.1007/s10551-018-3828-z

95 https://doi.org/10.1016/j.indmarman.2018.04.005

96 http://dx.doi.org/10.1016/j.indmarman.2015.11.012

97 https://doi.org/10.1016/j.indmarman.2018.03.014

98 http://dx.doi.org/10.1016/j.indmarman.2016.07.005

99 http://dx.doi.org/10.1057/jibs.2013.12

100 https://doi.org/10.1057/s41267-017-0108-6

101 http://dx.doi.org/10.1016/j.indmarman.2009.05.015

102 http://dx.doi.org/10.1016/j.jbusres.2013.02.037

103 http://dx.doi.org/10.1016/j.jwb.2016.07.009

$104 \mathrm{http} / / / \mathrm{dx}$.doi.org/10.1111/j.1467-6486.2010.00984.x

105 http://dx.doi.org/10.1002/smj.2791

106 http://dx.doi.org/http://dx.doi.org/10.1016/j.jbusres.2013.11.030

107 https://doi.org/10.5465/amp.2015.0125

108 https://doi.org/10.1057/s41267-018-0162-8

109 https://doi.org/10.1177/0266242616664798 
110 http://dx.doi.org/10.1177/0266242616667540

111 http://dx.doi.org/10.1016/j.intman.2017.09.006

112 http://dx.doi.org/10.1177/0266242614550190

113 http://dx.doi.org/10.1016/j.jwb.2017.05.004

114 http://dx.doi.org/10.1057/jibs.2015.8

115 http://dx.doi.org/10.1111/j.1467-6486.2008.00800.x

116 http://dx.doi.org/10.1016/j.ijresmar.2017.08.003

117 http://dx.doi.org/10.1111/etap.12058

118 http://dx.doi.org/10.1016/j.indmarman.2017.08.004

119 http://dx.doi.org/10.1016/j.jwb.2010.05.002

$120 \mathrm{http} / / / \mathrm{dx}$.doi.org/10.1111/j.1467-6486.2010.00951.x

121 https://doi.org/10.1111/j.1745-493X.2010.03209.x

122 https://doi.org/10.5465/amp.2009.39985538

123 https://doi.org/10.1080/08985620903233945

$124 \mathrm{http} / / / \mathrm{dx}$. doi.org/10.1007/s10551-014-2461-8

125 http://dx.doi.org/10.1016/j.indmarman.2012.10.004

126 http://dx.doi.org/10.1016/j.jwb.2016.05.004

127 http://dx.doi.org/10.1007/s10551-016-3071-4

128 https://www.jstor.org/stable/20788814

129 http://dx.doi.org/10.1016/j.indmarman.2015.07.010

130 http://dx.doi.org/10.1111/j.1467-6486.2009.00852.x

131 http://dx.doi.org/10.1016/j.jbusres.2017.05.017
132 https://doi.org/10.1016/j.pursup.2018.03.001

133 http://dx.doi.org/10.1016/j.indmarman.2017.07.006

134 http://dx.doi.org/1057/s41267-016-0034-z

135 http://dx.doi.org/10.1509/jmr.15.0204

136 https://doi.org/10.1016/j.jbusres.2018.12.045

137 http://dx.doi.org/10.1016/j.jbusres.2016.12.005

138 http://dx.doi.org/10.1002/smj.2787

139 http://dx.doi.org/10.1016/j.jwb.2015.12.001

140 http://dx.doi.org/10.1016/j.indmarman.2016.06.010

141 http://dx.doi.org/10.1016/j.indmarman.2013.02.009

142 http://dx.doi.org/10.1016/j.jbusvent.2012.02.003

143 http://dx.doi.org/10.1016/j.jbusres.2013.02.033

144 http://dx.doi.org/10.1002/sej.1268

145 http://dx.doi.org/10.1007/s11747-011-0253-6

146 http://dx.doi.org/https://doi.org/10.1080/10967494.2016.1 276036

147 http://dx.doi.org/10.1057/jibs.2012.27

148 http://dx.doi.org/10.1509/jmr.13.0318

149 http://dx.doi.org/10.1016/j.jbusres.2015.10.144

$150 \mathrm{http}: / / \mathrm{dx}$. doi.org/10.1057/jibs.2008.92

151 http://dx.doi.org/10.1057/jibs.2010.61

152 http://dx.doi.org/10.1016/j.jbusres.2014.01.007 


\section{APPENDIX A2}

Most repeated and cited items (Keyword groups)

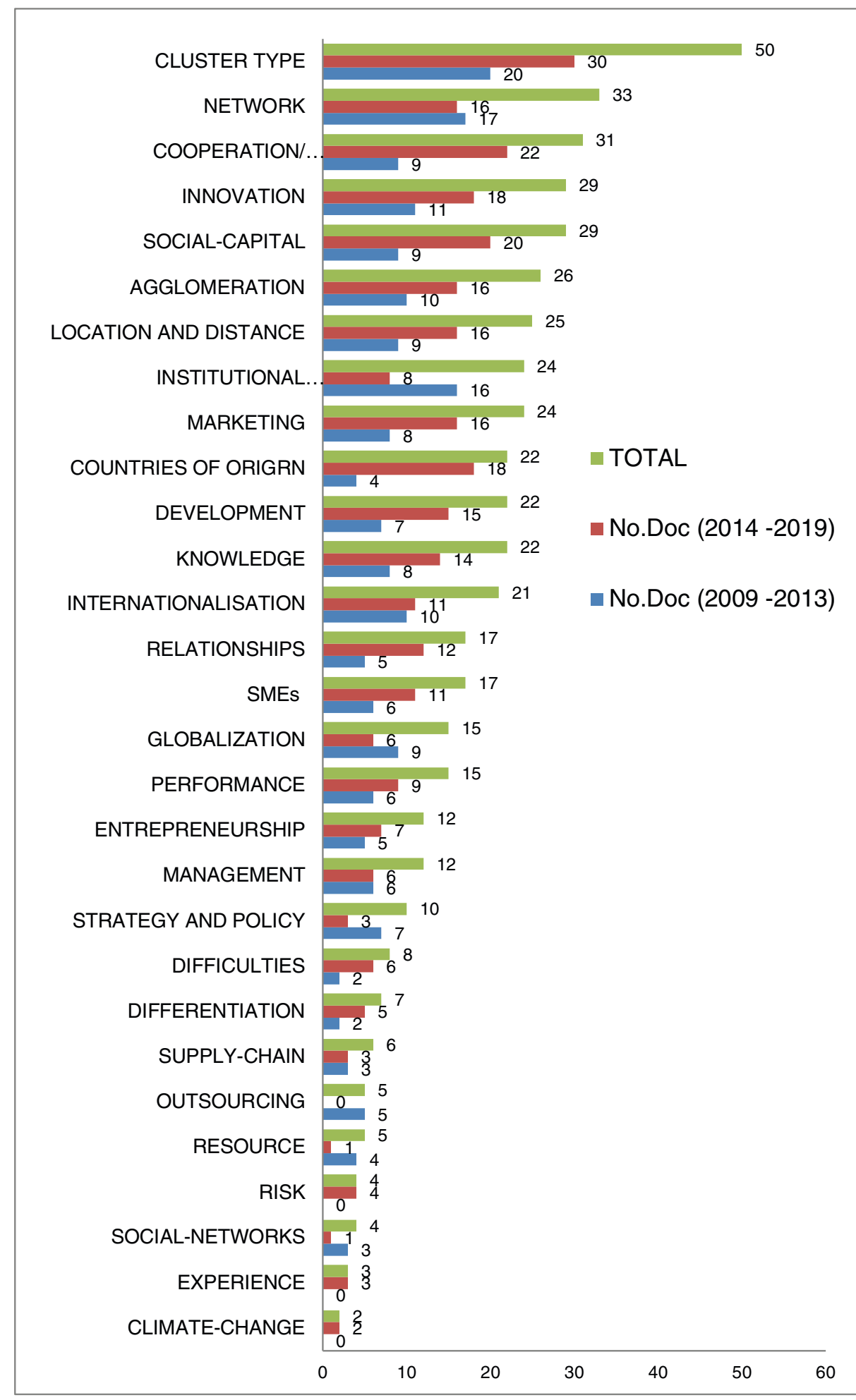

